\title{
Reproductive and Growth Characteristics During The First Age of Kıvırcık, Sakız and Gökçeada Indigenous Sheep Breeds
}

\author{
Tamer Sezenler $^{1 *}$, Ertan Köycü̈ ${ }^{2}$, Yalçın $\operatorname{Yaman}^{1}$, Ayhan Ceyhan $^{3}$ \\ Mustafa Küçükkebapçı ${ }^{1}$, Mehmet Akif Yüksel $^{1}$ \\ ${ }^{1 *}$ Bandirma Sheep Research Station, 10200 Bandirma/Ballkesir, Turkey \\ ${ }^{2}$ Namik Kemal University, Agriculture Faculty, Department of Animal Science, 59100 Tekirdag, Turkey.
}

${ }^{3}$ Nigde University, The Vocational School of Bor, 51700 Bor/Nigde,Turkey

\section{A R T I C L E I N F O}

\section{Article history:}

Received 21 January 2014

Accepted 26 February 2014

Available online, ISSN: $2148-127 \mathrm{X}$

Keywords:

Sheep

Oestrus cycle

Live weight

Lamb

Growth characteristics

${ }^{*}$ Corresponding Author:

E-mail: tsezenler@hotmail.com
A B S T R A C T

This study was conducted to determine first age reproduction characteristics of indigenous Kıvırcık, Sakız and Gökçeada sheep breeds and growth performances of ewe lambs which have been kept in Bandırma Sheep Research Station (BSRS). The data of reproduction characteristics of ewes and growth characteristics of lambs were collected on 15 Kıvırcık, 8 Sakız and 10 Gökçeada ewes, and on 16 Kıvırcık, 12 Sakız and 11 Gökçeada lambs, respectively. After the lambs completed their fifth month ages, estrus detection was carried out with a teaser ram twice a day with 12 hour intervals. For the Kıvırcık, Sakız and Gökçeada lambs, the first oestrus weights were 37.93, 33.35 and $29.75 \mathrm{~kg}$; first oestrus ages were 315, 320 and 337 days; oestrus durations were 30.99 , 25.85 and 20.28 hours and the duration of the oestrus cycles were 16.59, 19.91 and 17.76 days, respectively. The birth weights of Kıvırcık, Sakız and Gökçeada lambs were found to be $3.64,3.91,3.28 \mathrm{~kg}$; the weaning weight (WW), 31.01, 25.44 and $23.67 \mathrm{~kg}$, the six month live weight (SMLW), 32.87, 26.95 and $24.15 \mathrm{~kg}$, the yearling live weight (YLW), $39.01,30.95$ and $30.27 \mathrm{~kg}$ and the average daily weight gain (ADWG), 0.2710 .257 and $0.202 \mathrm{~kg}$, respectively.

\section{Kıvırcık, Sakız ve Gökçeada Yerli Irk Dişi Kuzuların İlk Yaş Üreme ve Büyüme Özellikleri}

\section{A K A L E B İ L G İ S İ}

Geliş 21 Ocak 2014

Kabul 26 Şubat 2014

Çevrimiçi baskı, ISSN: 2148-127X

Anahtar Kelimeler:

Koyun

Kızgınlık döngüsü

Canlı ağırlık

Kuzu

Büyüme özellikleri

\section{Ö Z E T}

Bu çalışma, Bandırma Koyunculuk Araştırma İstasyon'unda yetiştirilen Kıvırcık, Sakız ve Gökçeada yerli koyun ırklarımızın ilk yaş üreme özellikleri ve büyüme performansını belirlemek amacıyla yapılmıştır. Araştırmada ilk yaş üreme özellikleri için 15 baş Kıvırcık, 8 baş Sakız ve 10 baş Gökçeada dişi kuzu, büyüme özellikleri için ise 16 baş Kıvırcık, 12 baş Sakız ve 11 baş Gökçeada dişi kuzunun verileri kullanılmıştır. Kızgınlık tespitleri kuzuların beşinci ayını doldurması ile beraber arama koçları ile on iki saat arayla günde iki kez yapılmıştır. Kıvırcık, Sakız ve Gökçeada kuzularında ilk kızgınlık canlı ağırlı̆̆ 1 sırasıyla; 37,93; 33,35 ve 29,75 kg, ilk kızgınlık yaş1; 315, 320 ve 337 gün, kızgınlık süresi; 30,99; 25,85 ve 20,28 saat, kızgınlık siklusu; 16,59; 17,91 ve 17,76 gün bulunmuştur. Kıvırcık, Sakız ve Gökçeada dişi kuzuların doğum ağırlı̆̆ı sırasıyla; 3,64; 3,$90 ; 3,28 \mathrm{~kg}$, sütten kesim ağırlığı; 31,01; 25,44 ve 23,67 kg, altıncı ay canlı ağırlı̆̆1; 32,$87 ; 26,95$ ve $24,15 \mathrm{~kg}$, bir yaş canlı ağırlığ $1 ; 39,01 ; 30,95$ ve $30,27 \mathrm{~kg}$ ve günlük canlı ağırlık artışı; 0,$271 ; 0,257$ ve $0,202 \mathrm{~kg}$ bulunmuştur. 


\section{Introduction}

It is clear that sheep is one of the most important species widely distributed all over the world, having different production traits (meat, milk and wool) and high capacity of adaptation which allows it to survive in a great variety of environments from cold mountainous regions, arid zones to semi-deserts area. Simply defined, ewe reproduction is giving birth to offspring. The survival of lambs largely depends on their ability to reproduce its own lambs. Sheep reproduction consists of the chain of gamete production, fertilization, gestation, reproductive behaviour and lambing. Therefore, reproduction is vital and complex process in sheep, as being in all other living organisms.

Reproduction or insemination can be defined as the chain of inter-related biological events ranging from the creation of the reproduction cell to mating, gestation, birth and lactation and to reproduction again. The first condition for the production of elements necessary for life of plants and animals is to reproduce or fertilize. For the ewe lamb, sexual maturity or puberty is the development of the egg and desire to mate or display oestrus. The first time when ewe lambs display oestrus is called sexual maturity. The sexual maturity age of ewe lambs varies depending on the breed, live weight, feeding, birth date, year, and birth type. In general ewe lambs reach sexual maturity when they reach $40-60 \%$ of their mature age weight. This is possible for breeds that develop early and have long mating seasons to display oestrus during their first age. This is called sexual maturity or early development feature. Sexual maturity can be measured in terms of the percentage of the ewes that reach sexual maturity during their first age, percentage of ewes fertilized or the average age when oestrus is observed (Kaymakçı, 1994).

Growth performance of young animals kept for breeding is the period when they are not fruitful and are costly. Shorter this period, lower the costs for the establishment and higher the profitability of the establishments as a result of increased efficiency from the animals (Akçapınar and Özbeyaz, 1999). Thus, reproduction is a crucial process for livestock breeding. If animals fail to reproduce they can even face the threat of extinction. It can be said that reproduction allows more effective animal improvement activities and selection (Kaymakçı, 1984).

Kıvırcık, Sakız and Gökçeada sheep breeds have low percentage of total sheep population in Turkey. However, each breed has its unique reproductive efficiency qualities. K1vircık is known for its meat quality, Sakız is for its high litter size and Gökçeada is for its high milk yield and survival rate. Although the contribution of these breeds to animal production is limited, they can be used during the cross-breeding studies in the future particularly due to their high milk yield and litter size (Ertuğrul et al., 2000).

This study was conducted to determine the first age reproduction characteristics of indigenous Kıvırcık, Sak1z and Gokçeada sheep breeds and growth performances of lambs which have been kept in the Bandirma Sheep Research Station.

\section{Materials and Methods}

Location of Study

This study was conducted in Balıkesir provinces in Turkey. The sheep flocks were kept in Balıkesir province at Bandirma Sheep Research Station farm, located in the Marmara region of the country at longitude of $40^{\circ} 21 \mathrm{E}$, the latitude of $27^{\circ} 52 \mathrm{~N}$, and at altitude of $65 \mathrm{~m}$. The mean relative humidity ranges from $20 \%$ to $88 \%$ and the maximum and the minimum ambient temperature ranges from -14 to $42.4^{\circ} \mathrm{C}$. The annual rainfall in this area varies from 500 to $900 \mathrm{~mm}$ with an erratic distribution throughout the year (TSMS, 2012).

\section{Animals Material}

The data of reproduction characteristics were collected on 15 Kıvırcık, 8 Sakız and 10 Gökçeada ewes aged from 3 to 6 years old. In growth characteristics, the animal materials comprised 16 Kıvırcık, 12 Sakız and 11 Gökçeada lambs.

\section{Methods}

This study was carried out in the Bandirma Sheep Research Station (BSRS) in Turkey. Ewes were mated by hand mating method and it generally started between $15^{\text {th }}$ of June and $15^{\text {th }}$ of August at BSRS. Lambing was lasted from November $15^{\text {th }}$ and January $15^{\text {th }}$. The lambs were weaned starting from the beginning of April. Following the weaning, the ewe lambs from these three breeds were selected based on their ages and placed in a separate section. During the study, oestrus behaviour was determined by using the teaser rams described as the best method by Gökçen (1990) and starting from the beginning of June, four teaser rams were released among the ewes twice a day (at 9:00 am and 09:00 pm) and kept with the ewes for an hour every day during the research period. The reproductive organs of the rams were cleaned using special clothing before teasing to prevent unwanted pregnancies. In order to prevent the teaser ram from wasting time with ewes showing oestrus, they were immediately separated from the flock and placed in a separate section and the teaser rams were allowed to continue teasing. After the search was over, animals showing oestrus were brought back into the flock.

First Age Reproductive Characteristics: First age reproductive characteristics were calculated according to the method described by Kaymakçı (1984).

First oestrus age: It is the age when ewe lambs first display oestrus during their first year.

First oestrus weight: It is the live weight at the time when ewe lambs show first oestrus behavior.

Oestrus period: (number of) consecutive oestrus behaviour x 12 hours.

Oestrus Cycle: Period between the start of the first oestrus until the start of the second.

Growth traits: Within 12 hours after the birth of the lambs were weighed and ear tags. Their ear numbers, birth dates, birth types, and sex were recorded in the birth registration book. The birth weight (BW), weaning weight (WW), six month live weight (SMLW), yearling live 
weight (YLW) and first oestrus live weights (FELW) were measured using electronic scale sensitive to 100 grams. Daily weight gain (DWG) until weaning (90 day) was calculated by deducting the birth weight from the weaning live weight and dividing the difference by the age at weaning.

\section{Statistical Analyses}

The general linear model (GLM) was used to analyse the effect of breed, age of dam and the birth type on reproduction and growth characteristics. Significant differences among the means were compared by Duncantest. The statistical model is as follows:

$$
\mathrm{Y}_{\mathrm{ijkl}}=\mu+\mathrm{a}_{\mathrm{i}}+\mathrm{b}_{\mathrm{j}}+\mathrm{c}_{\mathrm{k}}+\mathrm{e}_{\mathrm{ijk}}
$$

where $y_{i j k l}$ is the trait of interest, $\mu$ is overall mean, $a_{i}$ is the effect of breed ( $i=$ Kıvırcık, Sakız, Gökçeada), $b_{j}$ is the effect of age of dam $(j=\leq 3,4-5 \geq 6), c_{k}$ is the effect of birth type ( $\mathrm{k}=$ single, twin) and $\mathrm{e}_{\mathrm{ijk}}$ is the random error term. The statistical analyses were carried out in SPSS (1999) 10.0. The results obtained were presented as least squares mean and standard error.

\section{Results and Discussion}

In the literature, publications are very limited on reproductive traits for native Turkish sheep breeds. Most studies have been published in different country and different sheep breeds, therefore the results of reproductive traits in this study have been discussed relative to findings for other sheep breeds.

\section{Reproductive Traits}

The first oestrus live weight and ages of the Kivircik, Sakız and Gökçeada sheep breeds are shown in Table 1. Average first oestrus live weights for these breeds were found to be $37.93,33.35$ and $29.75 \mathrm{~kg}$, respectively. The highest first oestrus live weight was observed in Kivircik breed and this was followed by Sakız and Gökçeada sheep breeds. The first oestrus live weight was the highest among the lambs of the ewes aged 4-5 years old, this was followed by the lambs of the ewes aged $\geq 6$ and $\leq 3$. The first oestrus live weights of the single born ewes were found to be higher than those of the twins born ewe.

The first oestrus age for the K1virc1k, Sak1z and Gökçeada breeds were found to be 315.13, 320.35 and 337.37 days, respectively, and the breeds that showed oestrus earlier displayed the same order as well. When the lambs were ranked according to first oestrus age based on the dam age, ewes aged $\leq 3$ years old displayed the earliest oestrus behavior and it was followed by the sheep aged 45 and $\geq 6$ years old. The first oestrus age of the single born lambs was found to be smaller than those of the twins born lambs.

The effect of breed as a factor influencing the oestrus live weight of the lambs was found to be statistically significant $(\mathrm{P}<0.01)$, but the effect of dam age and birth type were found to be insignificant. Similarly, the effect of breed, dam age and birth type on the first oestrus age was found to be insignificant.

In this study, the first oestrus live weights of Kivirc1k, Sakız and Gökçeada sheep (37.93, 33.35 and $29.75 \mathrm{~kg}$ ) were found to be lower than the reports by Dyrmundsson (1978) $39.00 \mathrm{~kg}$, Urrutia et al. (1994) $42.60 \mathrm{~kg}$, Saeid and Leroy (1997) $44.10 \mathrm{~kg}$, Sezenler et al. (2009) 45.30 and $47.30 \mathrm{~kg}$ and Urrutia et al. (1998) $45.00 \mathrm{~kg}$ and higher than the findings reported by Boshoff et al. (1975) 24.80, 24.40 and $31.70 \mathrm{~kg}$, Gonzales et al. (1980) $20.90 \mathrm{~kg}$, Suleiman (1981) 20.60, 21.80 and $17.50 \mathrm{~kg}$, Johnson et al. (1988) 19.10, 20.60, 23.40 and $20.80 \mathrm{~kg}$, Velazquez et al. (1995) 28.90, 24.00, 26.50 and $27.70 \mathrm{~kg}$ and Mukasa et al. (1995) $16.90 \mathrm{~kg}$ for the different sheep breeds. Moreover, our results are in general agreement with the finding by Keane (1974) $33.00 \mathrm{~kg}$, Kaymakçı (1984) $33.50,32.00,36.50$ and $34.90 \mathrm{~kg}$, Souza et al. (1995) $37.90 \mathrm{~kg}$.

The results of this study for the first oestrus age of Kıvırcık, Sakız and Gökçeada sheep (315.13, 320.35 and 337.37 day) are similar to those obtained by Velazquez et al. (1995) 311.30, 302.80, 261.30 and 329.00 days and were found to be higher than the reports by Keane (1974) 254 day, Boshoff (1975) 170, 163 and 224 days, Cedillo et al. (1977) 205 days, Dyrmundsson, (1978) 212.8 days, Cumlivski, (1979) 184, 185, 213, 210 and 270 days, Cumlivski (1980) 217.5 days, Gonzales et al. (1980) 286.2 days, Berger and Ginisty (1980) 250 days, Suleiman (1981) 194.9, 217 and 205.3 days, Boshoff (1984) 116 days, Kaymakçı (1984) 225.5, 217, 304.5, 301.2 and 289.8 days, Urruita et al. (1994) 202.1 days, Polskaya et al. (1988) 240 and 270 days, Johnson et al. (1988) 283, 294, 310 and 266 days, Sousa et al. (1995) 281.8 days, Mukasa et al. (1995) 300 days, Saeid and Leroy (1997) 244.7 days, Bathei (1996) 212 days. On the other hand, they were found to be lower than Mehta et al. (1995) 18 months and Gaillard (1979) 351.4 days in different sheep breeds.

Table 1. Least square means and standard errors of sheep breeds first oestrus live weight and age of ewe lambs

\begin{tabular}{|c|c|c|c|}
\hline Sources of Variation & & First oestrus live weight $(\mathrm{kg})$, Mean $\pm S E$ & First oestrus age (day), Mean $\pm S E$ \\
\hline Breeds & $\mathrm{n}$ & $* *$ & NS \\
\hline Kivirc1k & 15 & $37.93 \pm 1.022 \mathrm{a}$ & $315.13 \pm 8.483$ \\
\hline Sak1z & 8 & $33.35 \pm 1.518 b$ & $320.35 \pm 12.601$ \\
\hline Gökçeada & 10 & $29.75 \pm 1.263 b$ & $337.37 \pm 10.485$ \\
\hline Age of Dame & & N.S. & N.S. \\
\hline$\leq 3$ & 12 & $32.46 \pm 1.152$ & $323.48 \pm 9.564$ \\
\hline $4-5$ & 13 & $35.63 \pm 1.475$ & $323.88 \pm 12.247$ \\
\hline$\geq 6$ & 8 & $32.93 \pm 1.331$ & $325.48 \pm 11.051$ \\
\hline Birth Type & & NS & NS \\
\hline Single & 14 & $34.17 \pm 1.270$ & $323.97 \pm 10.546$ \\
\hline Twin & 19 & $33.18 \pm 0.966$ & $324.59 \pm 8.024$ \\
\hline Mean & 33 & $33.68 \pm 0.720$ & $324.28 \pm 5.979$ \\
\hline
\end{tabular}


The lengths of oestrus and oestrus cycles are given Table 2. The oestrus lengths were determined as 30.99, 25.85 and 20.28 hours for the Kivirc1k, Sak1z and Gökçeada breeds, respectively. The longest oestrus length was found to be in the lambs of ewes aged $\leq 3$ and this was followed by the lambs of ewes aged $\geq 6$ and $4-5$ years old. Single born lambs had longer oestrus length compared to twin born. The differences among the breeds in terms of oestrus length are significant $(\mathrm{P}<0.01)$, however, the effect of the dam age and birth type was insignificant $(\mathrm{P}>0.05)$

The oestrus cycle lengths for Kivircık, Sakız and Gökçeada sheep breeds were 16.59, 17.91 and 17.76 days, respectively. The longest oestrus cycle (18.03 days) was seen in the lambs of ewes aged 4-5 years old, and it was followed by the lambs of ewes aged $\geq 6$ and $\leq 3$ years old. In terms of oestrus cycle length, single born lambs showed longer oestrus cycle compared to twin born lambs In terms of oestrus cycle length, the effect of breed and birth type $(\mathrm{P}<0.01)$ and also the effect of dam age were found to be significant $(\mathrm{P}<0.05)$.

The oestrus length for the lambs of Kivircık, Sakız and Gökçeada sheep breeds were lower than the reports by Boshoff (1975) 36, 40.4 and 34.8 hours, Berger and Ginisty (1980) 36 hours, Boshoff (1984) 30, 36 hours, Aboul et al. (1984) 47, 37.7 and 37.5 hours, Toteda et al. (1987) 37.5, 37.7 and 47 hours, Mehta et al. (1995) 36 hours and Bathei (1996) 32.8 hours, and were found to be higher than those reported by Gaillard (1979) 18.4 hours and Sezenler et al. (2009) 19.4 and 21.2 hours. Also, they are similar to findings by Castillo et al. (1977) $29.7,31.2$ and 25.8 hours, Cumlivski (1979) 26, 27, 26, 26 and 28 hours, Cumlivski (1980) 26 hours, Gonzales et al. (1980) 26.7 hours and Kaymakçı (1984) 29.5, 34.8, 32, 28.6, 27.5 and 27.8 hours.

The values obtained for oestrus cycles length were higher than the results obtained by Cumlivski (1979), Gaillard (1979), Cumlivski (1980), Sabrh et al. (1992), Mehta et al. (1995) and Narayanaswamy (1976). Also, our the results are similar to findings of Berger and Ginisty (1980) 17.4 days, Gonzales et al. (1980) 17.6 days, Osterberg (1981) 18 days, Boshoff (1984) 17-18 days, Abaul et al. (1984) 17.4 and 17.02 days, Kaymakçı (1984) 15.7, 16.5, 17, 17.2, 16.4 and 17.5 days, Aboul et al. (1985) 17.8, 17.6 and 17.1 days, Elias (1985) 17.6 and 16.6 days, Toteda (1987) 17.8, 17.6 and 17.1 days, Mukasa et al. (1995) 17.9 days, Rosenmoller (1996) 17 days and Sezenler et al. (2009) 16.12 and 17.07 days. The differences between results related to reproduction traits in this study and those from other studies may be due mainly to genetic factor such as breed and some environmental factors such as feeding level of ewes and lambs, pre- and post-weaning growth characteristic of lambs, pastures quality and the management conditions of the ewes and lambs.

\section{Growth Traits}

The live weights of Kıvırcık, Sakız and Gökçeada ewe lambs in different period are present Table 3. The birth weights (BW) were $3.64,3.91$ and $3.28 \mathrm{~kg}$, the weaning weights (WW) were $31.01,25.44$ and $23.67 \mathrm{~kg}$, the sixth month live weights (SMLW) were 32.87, 26.95 and 24.15 $\mathrm{kg}$, yearling weights (YLW) were 39.01, 30.95 and 30.27 $\mathrm{kg}$, the average daily weight gains (ADWG) were 0.271, 0.257 and $0.202 \mathrm{~kg}$ in Kıvırcık, Sakız and Gökçeada lambs, respectively. The effect of breed on the BW, WW, SMLW, YLW and ADWG were found to be significant $(\mathrm{P}<0.05, \mathrm{P}<0.01)$ while the significant effect of dam age was observed only on YLW. The effect of birth type was significant only on $\mathrm{BW}$, but it was insignificant on the other weight traits.

BW values were found to be similar or slightly higher than those obtained by Özder et al. $(1999,2004) 3.51$ and $3.32 \mathrm{~kg}$, Esen and Ay (2004) $3.10 \mathrm{~kg}$, Ceyhan et al. (2004, 2007, 2009b) $3.49,3.62$ and $2.98 \mathrm{~kg}$, Akçapınar et al. (2005) $3.6 \mathrm{~kg}$, and Cemal et al. (2005) $3.41 \mathrm{~kg}$, but they were found to be lower than the values obtained by Sezenler et al. (2009) $4.08 \mathrm{~kg}$, Esen and Yildız (2000) $4.01 \mathrm{~kg}$, Akçapınar et al. (2000) 4.68, 4.57 and $4.51 \mathrm{~kg}$, Ceyhan et al. (2010) $4.20 \mathrm{~kg}$, Daşkıran et al. (2010) 4.43 $\mathrm{kg}$ and Koncagül et al. (2013).

The WW in this study were found to be higher than those obtained by the Özder et al. (1999, 2004) 19.35 and $19.89 \mathrm{~kg}$, Akçapınar et al. (2000, 2005) 21.179 and 18.7 $\mathrm{kg}$, Esen and Yild1z (2000) $20.88 \mathrm{~kg}$, Sezenler et al. (2009) $32.70 \mathrm{~kg}$, Ceyhan et al. (2007) and Koncagül et al. (2013) $22.1 \mathrm{~kg}$, and found to be similar to or lower than Ceyhan et al. (2010) 34.31 and $26.94 \mathrm{~kg}$ and Ceyhan et al. (2009b) $24.89 \mathrm{~kg}$.

Table 2. Least square means and standard errors of sheep breeds length of oestrus cycle and oestrus duration

\begin{tabular}{l|rcc}
\hline Source of Variance & & Oestrus Duration (hour), Mean $\pm S E$ & Oestrus Cycle (day), Mean $\pm S E$ \\
\hline Breeds & $\mathrm{n}$ & $* *$ & $* *$ \\
Kivircik & 15 & $30.99 \pm 1.457 \mathrm{a}$ & $16.59 \pm 0.213 \mathrm{~b}$ \\
Sakız & 8 & $25.85 \pm 2.149 \mathrm{ab}$ & $17.91 \pm 0.314 \mathrm{a}$ \\
Gökçeada & 10 & $20.28 \pm 1.570 \mathrm{~b}$ & $17.76 \pm 0.230 \mathrm{a}$ \\
Ages of Dam & $\mathrm{NS}$ & $*$ \\
$\leq 3$ & 12 & $26.63 \pm 1.615$ & $17.02 \pm 0.236 \mathrm{~b}$ \\
$4-5$ & 13 & $25.41 \pm 1.842$ & $18.03 \pm 0.269 \mathrm{a}$ \\
$\geq 6$ & 8 & $25.08 \pm 1.850$ & $17.21 \pm 0.271 \mathrm{~b}$ \\
Birth Type & $\mathrm{NS}$ & $* *$ \\
Single & 14 & $26.63 \pm 1.699$ & $18.00 \pm 0.249 \mathrm{a}$ \\
Twin & 19 & $24.79 \pm 1.307$ & $16.83 \pm 0.191 \mathrm{~b}$ \\
\hline Mean & 33 & $25.71 \pm 0.950$ & $17.42 \pm 0.139$ \\
\hline$* *: \mathrm{P}<0.01, *: \mathrm{P}<0.05$, NS: Not Significant . a,b,c: Means followed by the same letter in the same column are not significantly different at P<0.05.
\end{tabular}


Table 3. Least squares means and standard errors of lamb growth performance

\begin{tabular}{|c|c|c|c|c|c|c|}
\hline Source of Variance & & $\mathrm{BW}$, Mean $\pm S E$ & $\mathrm{WW}$, Mean $\pm S E$ & SMLW, Mean \pm SE & YLW, Mean $\pm S E$ & ADWG, Mean $\pm S E$ \\
\hline Breeds & $\mathrm{n}$ & $*$ & $* *$ & $* *$ & $* *$ & $* *$ \\
\hline Kivircik & 16 & $3.64 \pm 0.127 \mathrm{ab}$ & $31.01 \pm 0.815 \mathrm{a}$ & $32.87 \pm 0.924 \mathrm{a}$ & $39.01 \pm 1.147 \mathrm{a}$ & $0.271 \pm 0.007 \mathrm{a}$ \\
\hline Sak1z & 12 & $3.91 \pm 0.163 \mathrm{a}$ & $25.44 \pm 1.039 b$ & $26.95 \pm 1.179 b$ & $30.95 \pm 1.463 b$ & $0.257 \pm 0.009 b$ \\
\hline Gökçeada & 11 & $3.28 \pm 0.153 b$ & $23.67 \pm 0.978 b$ & $24.15 \pm 1.109 b$ & $30.27 \pm 1.376 b$ & $0.202 \pm 0.008 \mathrm{c}$ \\
\hline Ages of Dam & & NS & NS & NS & $*$ & NS \\
\hline$\leq 3$ & 14 & $3.39 \pm 0.146$ & $26.56 \pm 0.933$ & $27.71 \pm 1.058$ & $32.91 \pm 1.313 \mathrm{ab}$ & $0.239 \pm 0.008$ \\
\hline $4-5$ & 11 & $3.78 \pm 0.169$ & $27.03 \pm 1.079$ & $28.92 \pm 1.224$ & $34.16 \pm 1.519 a$ & $0.257 \pm 0.009$ \\
\hline$\geq 6$ & 14 & $3.66 \pm 0.145$ & $26.54 \pm 0.928$ & $27.34 \pm 1.052$ & $33.15 \pm 1.306 b$ & $0.234 \pm 0.008$ \\
\hline Birth Type & & $*$ & NS & NS & NS & NS \\
\hline Single & 17 & $3.78 \pm 0.138$ & $27.49 \pm 0.885$ & $28.34 \pm 1.004$ & $32.76 \pm 1.246$ & $0.248 \pm 0.007$ \\
\hline Twin & 22 & $3.44 \pm 0.115$ & $25.94 \pm 0.734$ & $27.64 \pm 0.832$ & $34.06 \pm 1.033$ & $0.238 \pm 0.006$ \\
\hline Mean & 39 & $3.61 \pm 0.082$ & $26.71 \pm 0.526$ & $27.99 \pm 0.597$ & $33.41 \pm 0.740$ & $0.243 \pm 0.004$ \\
\hline
\end{tabular}

The SMLWs are close to the findings obtained by Akçapınar et al. (2005) $27.0 \mathrm{~kg}$, while they are lower than those reported by Sezenler et al., (2009) $41.90 \mathrm{~kg}$, Ceyhan et al., (2004, 2007, 2009a, 2010) 33.158, 34.31, 34.96 and $33.21 \mathrm{~kg}$, Akçapınar et al., (2000) 33.92, 32.31 and 31.78 $\mathrm{kg}$, Daşkiran et al. (2010) $42.36 \mathrm{~kg}$ and Koncagül et al. (2013) $36.1 \mathrm{~kg}$. On the other hand, YLWs were found to be lower than those reported by Sezenler et al. (2009) $45.42 \mathrm{~kg}$, Ceyhan et al. (2007, 2009a) 39.52 and $41.14 \mathrm{~kg}$. The ADWGs until weaning were found to be similar to those determined by Ceyhan et al. (2009a, 2010) $269.3 \mathrm{~g}$ and 270.1, and higher than those reported by Ceyhan et al. (2007) 210 g, Esen and Y1ld1z (2000) $160 \mathrm{~g}$, and Tekin et al. (2005) $200 \mathrm{~g} / \mathrm{day}$. The differences between findings related to lamb growth traits in this study and those from other studies may be due to genetic and environmental factors such as breed, the milk yield of ewes, the lamb growth methods employed in the enterprise (farm), the suckling period, the type of birth and the sex of the lamb.

\section{Conclusion}

\section{Reproductive Traits}

It was found that the lambs of each of the three breeds reached puberty lower in terms of first oestrus live weight than those indicated in the literature, and they reached the first oestrus age later. The evaluation of the lengths of oestrus and oestrus cycle revealed that they are close to those indicated in the literature. As known, the sexual maturity varies according to age, breed and the level of care and nutrition. The results obtained for the first oestrus reproductive characteristics of the Kıvırcık, Sakız and Gökçeada breeds may be due to the fact that the maturity weights of the local breeds are relatively lower than those of the breeds used for comparisons and that they have different care and nutritional conditions as well as due to breed, age and sex.

\section{Growth Traits}

The differences observed in the growth characteristics of ewe lambs may be due to genetic and environmental factors such as breed, age of dam, birth type, management and care and nutritional conditions.

As a result, it was demonstrated that the first oestrus of the Kıvırcık, Sakız and Gökçeada breeds occurred during the first age of lambs. There are differences among the breeds in terms of the first oestrus live weight and that dam age and birth type has no effect on the first oestrus age and live weight.

\section{Acknowledgement}

The authors would like to thank the General Directorate of Agricultural Research and Policy (GDAR) for providing necessary facilities.

\section{References}

Aboul NAM, Maijala K, Aboul EMB. 1984. Oestrus and ovarian activity of Finnish ewe raised under subtropical vs. temperate conditions.10th International Congress on Animal Reproduction and artificial Insemination, June 10-14, Volume II. Brief communications. Paper no:127,3 pp.

Aboul NAM, Aboul EMB, Hassan FA. 1985. Comparative study of oestrus activity in Finn ewes and two Egyptian fattailed sheep under subtropical conditions. J Agri Sci UK 105: 469-473.

Akçapınar H, Özbeyaz C. 1999. Hayvan Yetiştiriciliği Temel Bilgileri.1 bask1, 70. Kariyer Matbaacılık Ltd Şti Ankara.

Akçapınar H, Özbeyaz C, Ünal N, Avcı M. 2000. Kuzu eti üretimine uygun baba hatlarının geliştirilmesinde akkaraman, Sakız ve Kıvırcık koyun ırklarından yararlanma imkanları. I. Akkaraman koyunlarda döl verimi, Akkaraman, Sakız x Akkaraman $F_{1}$ ve Kivırcık x Akkaraman $F_{1}$ kuzularda yaşama gücü ve büyüme. Turk $\mathrm{J}$ Vet Anim Sci 24: 71-79.

Akçapınar H, Ünal N, Atasoy F. 2005. The effect of early age mating on some production traits of Bafra (Chios $\mathrm{x}$ Karayaka $B_{1}$ ) sheep. Turk J Vet Anim Sci 29: 531-536.

Bathaei S. 1996. Breeding season and oestrus activity of Iranian fat-tailed Merhaban ewes and ewe lambs. Small Rum Res 22: 13-23.

Berger Y, Ginisty L. 1980. Results of 4 year study of the West African Dwarf breed of sheep in the Ivory Coast. Revue-d Elevage et de Medecine Veterinaire des Pays Tropicaux 33:71-78.

Boshoff DA, Burger FJL, Cronje JA. 1975. Sexual activity of Romanov-Karakul crosses under semi-arid conditions. South African J Anim Sci., 5: 91-94.

Boshoff DA. 1984. Reproduction of Karakul SheepYearbook. Karakul Breeders Society of Southern Africa. Ed, 26: 27-45.

Castillo RH, Hernandez LJJ, Berruecos JM, Lopez AJJ. 1977. Reproductive performance of Tabasco lambs in a tropical environment. 3. Puberty and duration of oestrus.Tecnica Pecuaria en Mexico 32: 32-35.

Cedillo R, Hohenboken M, Drummond J. 1977. Genetic and environmental effects on age at first oestrus and on wool and lamb production of crossbred ewe lambs. J Anim Sci, 44: 948-957.

Cemal İ, Karaca O, Altın T, Kaymakçı M. 2005. Live weights of Kivircik ewes and lambs in some under extensive management conditions. Turk J Vet Anim Sci 29:13291335.

Ceyhan A, Torun O, Erdoğan İ. 2004. İmroz, Kıvırcık ve Merinos yerli koyun irklarının verim performansları. Çukurova Üniv Zir Fak Derg 19: 11-20. 
Ceyhan A, Erdoğan İ, Sezenler T. 2007. Some Production Characteristics of Kivırcik, Gokceada and Sakız Breeds of Sheep Conserved as Gene Resources. Journal of Tekirdag Agricultural Faculty 4: 211-218.

Ceyhan A, Sezenler T, Erdoğan İ, Yıldırır M. 2009a. Fertility Traits, Survival Rate and Growth Characteristics of Crossbred Blackhead Merino (German Black Head Mutton $\mathrm{x}$ Karacabey Merino $\mathrm{B}_{1}$ ) Ewes. Journal of Animal Production 50: 1-8.

Ceyhan A, Koncagül S, Sezenler T. 2009b. The Effect of Inbreeding on Birth and Weaning Weights of Indigenous Gokçeada Sheep. J Agric Fac HR.Ü 13: 1-10.

Ceyhan A, Sezenler T, Yıldırır M, Erdoğan İ. 2010. Reproductive performance and lamb growth characteristics of Ramlıç sheep. Kafkas Univ Vet Fak Derg 16: 213-216.

Cumlivski B. 1979. Sexual maturity of lamb ewes and fertility of sheep with the highest reproduction efficiency. Paper 30 th Annual Meeting European Association for Animal Production No: MS4.5, 3 pp.

Cumlivski B. 1980. Reproductive performance of East Friesian ewes maintained in a large flock. Zivocisna Vyroba 25: 379386.

Daşkıran İ, Koncagül S, Bingöl M. 2010. Growth Characteristics of Indigenous Norduz Female and Male Lambs. Tarım Bilimleri Dergisi, 16: 22-29.

Düzgüneş O, Kesici T, Gürbüz F. 1983. İstatistik Metodları I. Ankara Üniversitesi Ziraat Fakakültesi Yayınları, 861, Ders kitabi: 229. Ankara.

Dyrmundsson OR. 1978. Studies on the breeding season of Icelandic ewes and ewe lambs. Journal of Agricultural Science 90: 275-281.

Elias E, Cohen D, Dayenoff P. 1985. Characterisics and indices of reproduction in Dorper sheep. J South African Vet Ass 56: $127-130$.

Ertuğrul M, Akman N, Dellal G, Goncagül T. 2000. Hayvan gen kaynaklarının korunması ve Türkiye hayvan gen kaynakları. Türkiye Zir Müh V. Teknik Kongresi. Yayın No:38, Ankara.

Esen F, Yıldız N. 2000. Akkaraman, Sakız x Akkaraman melez $\left(\mathrm{F}_{1}\right)$ kuzularda verim özellikleri. I. Büyüme, yaşama gücü, vücut ölçüleri. Turk J Vet Anim Sci 24: 223-231.

Esen Y, Ay G. 2004. Sakız x Akkaraman melez kuzuların ( $g_{1}$ ve $\mathrm{g}_{2}$ ) büyüme ve yaşama gücü özelliklerinin karşılaştırılması. Fırat Ünivversitesi Sağl1k Bilimleri Derg 18: 41-44.

Gaillard Y. 1979. Reproductive characteristics of the Uda ewe. Revue d'Elevage et de Medecine Veterinaire des Pays Tropicaux 32: 285-290.

Gonzalez SC, Goycochea LJ, Perozo GF. 1980. Reproductive performance of West African sheep in a tropical zone. 9th International Congress on Animal Reproduction and Artificial Insemination, 16th-20th June 1980. III. Symposia (free communications), 51.

Gökçen H. 1990. Evcil Hayvanlarda Seksüel Sikluslar. Alaçam E.(Ed): Theriogenoloji.1. 33-38, Nurol Matbaacılık A.Ş., Ankara.

Johnson WL, Barros NN, Oliviera ER, Simpliacute AA, Riera GGS. 1988. Dietary energy levels and age and weight at puberty in Morada Nova ewe lambs in Northeast Brazil. Small Rum Res 1: 67-72.

Kaymakçı M. 1984. Kimi yerli koyun ırklarında temel dölerme özelliklerinin değişimi üzerinde araştırmalar. Çayır-Mer'a ve Zootekni Araştırma Enstitüsü Yayın No: 92.

Kaymakçı M. 1994. Üreme Biyolojisi. 2. Baskı, 206. Ege Üniv Zir Fak Yayınları, İzmir.

Keane MG. 974. Effect of bodyweight on attainment of puberty and reproductive performance in Suffolk $x$ ewe lambs. Irish Journal of Agricultural Res, 1974, 13: 263-274.

Koncagül S, Vural ME, Karataş A, Akça N, Bingöl M. 2013. Reproductive Performance of Ewes and Growth
Characteristics of Lambs in Zom Sheep Reared in Karacadağ District. Kafkas Üniv Vet Fak Derg 19: 63-68.

Mehta SC, Vij PK, Nivsarkar AE, Sahai R. 1995. Sheep husbandry practices in Somadi and Malpura breeding tract. Indian J Small Rum 1: 1-7.

Mukasa M E and Lahlou K A. 1995. Reproductive Performance and Productivity of Menz Sheep in the Ethiopian Highlands. Small Rum Res 17: 167-177.

Narayanaswamy M, Balaine DS. 1976. A note on the oestrus cycle in Bannur sheep. Indian Veterinary Journa, 53: 235236.

Osterberg S. 1981. Breeding season of the Finnsheep ewe. Acta Agriculturae Scandinavica 31: 11-16.

Özder M, Soysal Mİ, Kaymakçı M, Kızılay E, Sönmez R. 1999. Türkgeldi koyun sürüsünde tipin sabitleştirilmesi. Turk J Vet Anim Sci 23:167-175.

Özder M, Kaymakçı M, Taşkın T, Köycü E, Karaağaç F, Sönmez R. 2004. Türkgeldi koyun tipinin gelişme ve süt verim özellikleri. Turk J Vet Anim Sci 28: 195-200.

Polskaya PI, Povarina TD, Kalashchuk GP, Alekseeva LS. 1988. Reproductive abilility of sheep of Askanian breeding. Nauchtekh Byull. Ukr. NII. Zhivotnovod Step. Raionov, 2: 6-12.

Rosenmoler R. 1996. Ethological and endocrinological investigations on the reproductive process in Skudde and Heidschnucke sheep with special reference to the seasonality of oestrus. Tierklinik fur Fortpflanzung, Fachbereich Veterinarmedizin, Freie Universitat Berlin, Germany, 342 pp; 174 Ref.

Sabrh HA, Shalash MR, Ashoub MR, Al Wakeel AM, Hassan SG. 1992. Effect of stocking density, age and body weight on some reproductive performance of Barki ewes. Egyptian Journal of Veterinary Science 29: 47-54.

Saeid BS, Leroy PL. 1997. Note on age and body weight at puberty in Merhaban Iranian fat-tailed ewe lambs. Tropical Animal Health and Production 29: 55-59.

Sezenler T, Ceyhan A, Yaman Y, Küçükkebapçı M, Yüksel MA. 2009. Reproductive and Growth Chacteristics First Age of Bandirma-I and Bandirma-II Crossbred Ewe Lambs. Journal of Tekirdag Agricultural Faculty 6: 265-272.

Sousa J, Leitao RM, Marques LR. 1995. Reproductive traits in Romney ewes on Santa Maria Island (Azores). Veterinaria Tecnica 5: 12-19.

SPSS. 1999. SPSS Base 10.0 User's Guide. SPSS inc., Chicago, IL, USA.

Suleiman AH. 1981. Some reproductive characteristics of female Shugor, Dubasi and Watish sheep reared at EL Huda Sheep Research Station. East African Agricultural and Forestry Journal 47: 49-54.

Tekin ME, Gürkan M, Karabulut O, Düzgün H. 2005. Performance testing studies and selection of Hasmer, Hasak, Hasiv and Limner crossbreed sheep types: II. Pre-weaning growth. Turk J Vet Anim Sci 29: 59-65.

Toteda F, Manchisi A, Bufano G, Martemucci G, Drio C. 1987. A study of Romanov sheep: 1. Reproductive performance. Archivio Veterinario Italian 38: 109-115.

TSMS. 2012. Turkish State Meteorological Service (TSMS). http://www.mgm.gov.tr. Access: 21.12.2012.

Urruita MJ, Ochoa CMA, Carrera BB. 1994. Age and body weight at puberty in housed Rambouillet ewe lambs. Revista Latinoamericana de Pequenos Rumiantes 1:134-139.

Urruita MJ, Ochoa CMA, Penuelas GG. 1998. Effect of lambing season on age at first oestrus in Rambouillet ewe lambs.Tecnica Pecuarias en Mexico 36: 15-23.

Velazquez IA, Cruz LC, Alvarez LJA. 1995. Effect of level of feed supplements on the time of first oestrus in Tabasco ewes born in summer.Veterinaria Mexico 26: 107-111. 